\title{
The Relation Between Trace Element Status (Zinc, Copper, Magnesium) and Clinical Outcomes in COVID-19 Infection During Pregnancy
}

\author{
Ali Taner Anuk \\ Ankara City Hospital
}

Naci Polat

Ankara University

Sevginur Akdas

Ankara University

Seyit Ahmet Erol

Ankara City Hospital

Atakan Tanacan

Ankara City Hospital

\section{Derya Biriken}

Ankara University

Huseyin Levent Keskin

University of Health Sciences

Ozlem Moraloglu Tekin

University of Health Sciences

Nuray Yazihan ( $\sim$ nurayyazihan@yahoo.com )

Ankara University

Dilek Sahin

University of Health Sciences

\section{Research Article}

Keywords: Copper, COVID-19, magnesium, infection, pregnancy, zinc

Posted Date: October 6th, 2020

DOI: https://doi.org/10.21203/rs.3.rs-88054/v1

License: (c) (1) This work is licensed under a Creative Commons Attribution 4.0 International License.

Read Full License 
Version of Record: A version of this preprint was published at Biological Trace Element Research on November 24th, 2020. See the published version at https://doi.org/10.1007/s12011-020-02496-y. 


\section{Abstract}

Background: SARS CoV-2 is a novel coronavirus which cause recent pandemia and many deaths. This study aimed to determine zinc, copper and magnesium status on pregnant women with COVID-19.

Methods: Totally 200 pregnants were included in the study, 100(34/33/33) were pregnants with COVID-19 infection and $100(33 / 32 / 35)$ were healthy pregnants and each group was divided into trimesters. Blood samples for trace element measurements were obtained from the patients along with the initial laboratory tests for clinical outcomes upon their first admission to hospital.Zinc, copper and magnesium levels were analyzed with atomic absorption spectroscopy.

Results: In the first/third trimesters, serum zinc level was lower (p:0,004)/(p:0,02), serum copper level was higher $(\mathrm{p}: 0,006) /(\mathrm{p}: 0,008), \mathrm{Zn} / \mathrm{Cu}$ ratio was decreased $(\mathrm{p}<0,0001) /(\mathrm{p}<0,0001)$ and serum magnesium level was also higher $(p<0,0001) /(p<0,0001)$ in COVID-19 group compared to control. Pregnants with COVID-19 in their second trimester had lower serum zinc level (p:0,05) and also copper level was decreased ( $p: 0,0003)$ compared to control. Our correlation results showed that serum zinc and $\mathrm{Zn} / \mathrm{Cu}$ ratio levels had negative relation with acute phase markers such as IL-6, Erythrocyte Sedimentation Rate, procalcitonin and Creactive Protein. Also, increased serum magnesium level might have role on decreased white blood cell, neutrophil, lymphocyte cell concentrations and there was correlation between serum magnesium and CRP level in the third trimester.

Conclusion: This study indicated that trace element status changed in pregnants with COVID-19. With the further studies,it will be clarified that the effects of trace elements on COVID-19 in pregnant and in general population which was shown with this study first time to date.

\section{Introduction}

SARS-CoV is a virus which is capable to bind the angiotensin-converting enzyme 2 receptor that present in human body in several locations such as lung alveolar epithelial cells, enterocytes, endothelial cells and arterial smooth muscle cells. This novel coronavirus cause recent pandemia and many deaths. Evidence to date suggests that in the severe COVID-19 cases, cytokine storm syndrome accompanies the infection.

In a systematic review of 385 pregnant women from 33 studies with COVID-19, it was shown that $95.6 \%$ of pregnants was mild, $3.6 \%$ was severe and $\% 0.8$ was critical stage of infection. Seventeen of pregnants needed intensive care of whom six were mechanically ventilated and one had maternal mortality. In totally 252 women who gave birth, $69.4 \%$ of them had cesarean section and $30.6 \%$ of them had normal delivery. Four of the newborns were SARS-CoV-2 positive, there were two stilbirths and one neonatal death [1].

According to data obtained from 108 pregnants with COVID-19, the women who were delivered by cesarean section (91\%), lymphocytopenia was reported in the $59 \%$ of them with elevated C-reactive 
protein levels (70\%) [2]. In an another systematic review study of pregnants with COVID-19 was concluded that the adverse outcomes are not common however our knowledge is still very limited about SARS-COV-2 and its effects on pregnancy [3].

The recent studies showed that zinc status is a critical factor that can influence antiviral immunity, particularly as zinc-deficient populations are mostly at risk of acquiring viral infections. Zinc is an component of many viral enzymes, proteases, and polymerases and cellular and systemic zinc homeostasis have the importance to prevent the viral infections. Despite the lack of clinical data, certain indications suggest that modulation of zinc status may be beneficial in COVID-19. In vitro experiments of Velthuis et al., it was shown that $\mathrm{Zn}^{+2}$ cations especially in combination with zinc ionophore pyrithione were shown to inhibit SARS-coronavirus RNA polymerase activity by decreasing its replication [4]. Also pregnant women need more zinc intake because of its quite important roles for both maternal and neonatal health such as fertility for pre-pregnancy, on growth and development during pregnancy and the neonatal period [5]. But the association between the zinc level in pregnancy and COVID-19 is still unclear.

In humans, copper is involved in the structure of cytochrome 10 and steps associated with oxidative stress, but high copper levels may have negative effects during inflammation. The balance between zinc and copper is important for the zinc to neutralize the negative effects that copper may cause.

Furthermore copper is an essential trace element for pathogens as well as for humans[6]. As a common feature of the infection, regardless of the agent (virus, bacteria, fungi), there is a progressive increase in serum copper [7-9]. But, there is no data about copper levels during COVID-19 infection not only in pregnant women but also in adults.

Magnesium is one of the important ion which is required as cofactor for ATP enzyme that is involved in many essential enzymatic reactions. It has also immune importance that $\mathrm{Mg}^{2+}$ has role on $\mathrm{CD}^{+} \mathrm{T}$ cell acitvation in infection by regulating the active sites of specific kinases [10]. Recent study showed that serum magnesium level might have protective effect against the lung function loss in asthma-chronic obstructive pulmonary disease, that is important result to understand potential relation between magnesium and pulmonary outcomes of COVID-19 disease [11]. To our knowledge, there is no study evaluating the relationship between magnesium and COVID-19 infection prior to this study. Also, it is of additional importance to evaluate pregnant COVID-19 patients because magnesium is a frequently used trace element for treatment $[12,13]$ during pregnancy.

This study aimed to assess zinc, copper and magnesium status on pregnant women with COVID-19 comparing with healthy controls when evaluated clinical outcomes with pregnancy trimesters for better understanding role of these three vital trace elements on pregnancy with SARS-CoV-2 infection for the first time.

\section{Material And Methods}

\section{Study Groups \& Ethics}


Pregnant women who were admitted to Department of Obstetrics and Gynecology, Turkish Ministry of Health Ankara City Hospital between 11 May 2020 and 30 August 2020 were included in the study and divided into SARS-CoV-2 positive and control group with similar clinical and demographic characteristics when the results of Real-time polymerase chain reaction (RT-PCR) assay of a nasopharyngeal and oropharyngeal specimen are evaluated [14]. Both Turkish Ministry of Health and institutional ethics committee approved the study protocol (E1-20-1009) and informed consent was obtained from all patients. All COVID-19 cases were managed with guidance by the national guideline.

\section{Examination of Biochemical and Clinical Profile}

Blood samples were obtained from the patients along with the initial laboratory tests upon their first admission to hospital. Demographic features, clinical characteristics and laboratory parameters were analyzed. Maternal age, body-mass index $(\mathrm{BMI})\left(\mathrm{kg} / \mathrm{m}^{2}\right)$, gravidity, parity, comorbid conditions, gestational age, pregnancy status, obstetric complications, hemoglobin $(\mathrm{Hb})$, hematocrit (Hct), white blood cell, platelet, lymphocyte, neutrophil counts, erythrocyte sedimentation rate (ESR), C-reactive protein (CRP), procalcitonin, interleukin 6 (IL-6), ferritin, blood urea nitrogen (BUN), creatinine, liver function tests (Aspartat Aminotransferase, Alanine Amino Transferase) were obtained to determine biochemical and clinical profile of patients.

\section{Measurement of Tissue Trace Element Concentrations}

Zinc, copper and magnesium levels were analyzed with atomic absorption spectroscopy. Perkin Elmer Analyst 800 device and "WinLab32" program were used for atomic absorption spectroscopy method. The calibration curve generate following to guideline with standard solutions of each trace element, 2 repetitive measurements of each sample were measured [15].

\section{Statistical Analysis}

IBM SPSS Statistics 25 (Armonk, NY, USA) software was used for statistical analysis. Student T test was used to analyse differences between study groups and Pearson correlation was used for correlation analysis between data. Graphpad PRISM 6.0 (La Jolla, CA, USA) was used for visualizing the data.

\section{Results}

A Totally 200 pregnant women were included in this study, the number of pregnants with COVID-19 infection were 100 and the other 100 patients were also healthy pregnant women. Each group was divided into trimesters: Respectively Thirty four, 33 and 33 patients were in the first, second and third trimesters of pregnancy in the COVID-19 group. On the other hand, 33, 32 and 35 patients were in the first, second and third trimesters of pregnancy in the control group, respectively.

In the first trimester, serum zinc level was found significantly lower in pregnants with COVID-19 compared to control $(67,19 \pm 13,87$ vs $55,97 \pm 16,57$, p: 0,004$)$. However serum copper level was higher in 
patient group than in control ones $(86,56 \pm 19,70$ vs $100,4 \pm 19,73, \mathrm{p}: 0,006)$ that cause important difference in $\mathrm{Zn} / \mathrm{Cu}$ ration between groups $(0,811 \pm 0,219$ vs $0,563 \pm 0,144, p<0,0001)$. Serum Magnesium level was also significanly higher in COVID-19 group compared to control $(1,557 \pm 0,211$ vs $1,848 \pm 0,335$, $\mathrm{p}<0,0001$ ) (Fig 1).

It was observed that zinc and copper levels were different between patient and control group during second trimester. Serum zinc level was observed lower level in pregnants with COVID-19 than control similar to first trimester $(52,84 \pm 12,57$ vs $46,38 \pm 12,66, p: 0,05)$. Although serum copper level was higher in patients in first trimester, it was seen that copper level was decreased in SARS-CoV-2(+) group compared to control $(157,2 \pm 22,16$ vs $132,6 \pm 26,66, \mathrm{p}: 0,0003)$. $\mathrm{Zn} / \mathrm{Cu}$ ratio $(0,339 \pm 0,081$ vs $0,351 \pm$ $0,077, \mathrm{p}: 0,529)$ and magnesium level $(1,759 \pm 0,195$ vs $1,817 \pm 0,387, p: 0,467)$ wasn't found different between groups in second trimester.

Third trimester data showed that serum zinc level was lower in COVID-19 group than controls (54,37 \pm $13,57$ vs $46,82 \pm 12,51, p: 0,02)$. Serum copper level was found higher again in COVID-19 group compared to control similar to first trimester results $(152,8 \pm 45,27$ vs $180,5 \pm 40,56, \mathrm{p}: 0,008)$. $\mathrm{Zn} / \mathrm{Cu}$ ratio was found significantly lower in pregnants with COVID-19 infection compared to control $(0,411 \pm 0,129 \mathrm{vs}$ $0,276 \pm 0,103, p<0,0001)$. Serum magnesium level was found significantly higher in COVID-19 group compared to healthy pregnants $(1,947 \pm 0,657$ vs $2,767 \pm 0,394, p<0,0001)$.

\section{Correlation Analysis}

In the first trimester, zinc concentration significantly correlated with IL-6 level (p:0.003, r:-0.357)and ESR ( $p: 0.01, r:-0,312)$. Copper concentration showed correlation with WBC (p:0.03, r:-0.263), procalcitonine ( $p: 0.03, r: 0.262)$, ALT ( $p: 0.02, r: 0.277)$ and AST ( $p: 0.01, r: 0.298)$ levels. There were correlations between Zn/Cu Ratio and IL-6 (p:0.01, r:-0.306), lymphocyte (p:0.01, r:-0.217),ESR (p:0.0009, r:-0.404), procalcitonin (p:0.03, r:-0.270). Magnesium concentration of pregnants was correlated with WBC (p:0,0003, r:-0,435), Neutrophil (p:0,002, r:-0,366), Lymphocyte (0,002, r:-0,378), ESR (p:0,001, r:0,384), hemotocrit (p:0.02, r:-0.276) and creatinine (p:0,04, r:-0,250).

Second trimester data of pregnant women showed that serum zinc level correlated with procalcitonin ( $p: 0.04, r:-0.254)$ and BUN (p:0.02, r:0.279). Copper level was correlated with IL-6 (p:0.01, r:-0.312), WBC (p:0.02, r:0.295), Neutrophil (p:0.03, r:0.264), Lymphocyte (p:0.01, r:0.308), CRP (p:0.008, r:-0.334), procalcitonin ( $\mathrm{p}: 0.01, \mathrm{r}:-0.327)$, ferritin ( $\mathrm{p}: 0.008, \mathrm{r}:-0.334)$, hemoglobin ( $\mathrm{p}: 0.008, \mathrm{r}: 0.335)$, hematocrit ( $\mathrm{p}$ : $0.008, r: 0.333)$, BUN (p:0.01, r:0.298), creatinine (p:0.03, r:0.271) .

Third trimester correlation data showed that zinc level correlated with CRP (p:0.004, r:-0.360). Copper level was found to be correlated with Lymphocyte (p:0.01, r:0.355), ALT (p:0.02, r:0.278) . Zn/Cu ratio was correlated with IL-6 (p:0.01, r:-0.308), CRP ( $\mathrm{p}: 0.004, \mathrm{r}:-0.463)$ levels. Magnesium concentration correlated with Lymphocyte (p:0.04, r:-0.254), CRP (p:0.03, r:0.271), ferritin (p:0.03, r:-0.272) and creatinine (p:0.01, r:0.306) status. 


\section{Discussion}

\section{Impaired Balance of Zinc and Copper in Pregnants with COVID-19}

Our study demonstrates that serum zinc level has relation with infection and inflammation status. As we mentioned before, serum zinc levels were decreased in COVID-19 patients in all trimesters compared to healthy women. Also serum zinc levels from different trimesters were found negatively correlated with acute phase markers such as IL-6, ESR, procalcitonin and CRP.

Zinc is well-known with its regulatuary character on inflammatory responses via Nuclear Factor Kappa $\mathrm{B}(\mathrm{NF}-\mathrm{KB})$ signalling pathway to control oxidative stress and inflammatory cytokines [16]. However, during the acute-phase of infection, zinc uptake into cells increase and zinc is placed within zincosome or organelles, which may lead to decreased serum zinc levels. Also, during acute phase response, urinary zinc excretion was shown to be increased and it was found to be correlated with CRP [17]. As a key cytokine of acute phase response of human body, IL-6 is important for diagnosis, and prognosis in different diseases based on immunity $[18,19]$. IL- 6 was observed to stimulate the zinc transporter (ZIP14) which places in cell membrane and function to zinc entering into cells [20,21]. Therefore, with these mentioned mechanisms, zinc has importance on inflamatory response and tends to decrease during acute phase by increased zinc uptake into cells which indicates that maintanance of serum zinc level is necessary in pregnant women with infection.

Recent study on COVID-19 patients showed that the patients with low zinc level were found higher complication rate (p:0.009), prolonged hospital stay (p:0.05), received corticosteroid therapy (p:0.02)and increased mortality rates $(18.5 \%$ vs $\% 0)$. Odds ratio of complications with low level serum zinc was found to be 5.54 [22]. Our study was the first study which investigates zinc status in pregnant women with COVID-19 and similar results were found about zinc and COVID-19 relation such as in the literature.

Our data showed that serum copper level elevated in pregnant women with COVID-19 in first and third trimester besides natural increase during pregnancy as it can be seen in Figure 4. We observed control serum copper levels increased during the trimesters but according to $t$ test results, COVID-19 patients had higher copper level than control. Our study is the first study which indicates higher serum copper levels in COVID-19 infection however considering the other infectious diseases, there are similar results in the literature. Huang et al showed that serum copper and urinary copper levels were increased in chronic Hepatitis B patients compared to control [23]. Serum copper level was found higher in HIV patients compared to control [24].

The decrease in zinc level with increase in copper level leads to very significant decrease in $\mathrm{Zn} / \mathrm{Cu}$ Ratio of pregnant women with COVID-19 infection. It is well-known that zinc and copper have balanced mechanism in human body therefore these results suggest that impaired $\mathrm{Zn}$-Cu balance is also related with outcomes. As it can be seen in correlation analysis, $\mathrm{Zn} / \mathrm{Cu}$ ratio showed correlation with inflammatory and acute phase markers including IL-6, CRP, ESR, procalcitonin. 


\section{Is the increase in magnesium levels cause or consequence?}

As an important result of our study, serum magnesium level was increased during pregnancy in COVID-19 group and it was observed that serum magnesium levels were higher in COVID-19 pregnant women in the first and third trimesters than control pregnant women. Our correlation results showed that serum magnesium level might have negative role on WBC, neutrophil, lymphocyte cell concentrations and which might explain the correlation between serum magnesium level and CRP level in the third trimester. These results indicate that higher level magnesium might have negative role on COVID-19 infection or infection cause higher level of serum magnesium in pregnant women. This is the first study which showed magnesium status in pregnant women with COVID-19 infection. However, considering the other cases in the literature there are interesting results.

In the study of Hafizi et al., they observed higher level of serum magnesium in helicobacter pylori positive kidney transplant patients compared to helicobater pylori negative ones ( $p: 0,0005)$. They mentioned that higher level of magnesium might aggravates $\mathrm{H}$. pylori infection in kidney transplant patients [25].

It was observed in an another study on visceral leishmaniasis $(\mathrm{VL})$ infectious disease that chronic LV patiens had significantly higher serum magnesium level compared to both acute LV patients and healthy controls. They suggests that higher level of serum magnesium may down-regulate nitric oxide production which may be related to the chronic state of the disease. Also $\mathrm{Mg}^{2+}$ dependent ecto-ATPase activity in parasite may avoid the microbicidal activity of macrophages. Furthermore they found the decreased level of zinc and increased level of copper as well as increased level of magnesium in only chronic VL patients which researcher thought that might be predictive for clinical evaluation of chronic stage of VL infection [26]. Another similar result was observed in malaria patients that serum magnesium level was increased nearly 3 fold than controls. They mentioned increase of magnesium levels might be depended on hemolysis because red blood cells contain high amounts of magnesium [27]. In another study the association was found with magnesium levels on admission and 30-day mortality in patients with pneumonia. While hypomagnesemic $(<1.35 \mathrm{mg} / \mathrm{dl})$ patients had $18.8 \%$ mortality, normomagnesemic $(1,35-2 \mathrm{mg} / \mathrm{dl})$ patients had $14.8 \%$ and hypermagnesemic $(>2.4 \mathrm{mg} / \mathrm{dl})$ had $50 \%$ mortality ratio. Even, magnesium levels within the upper normal limit (2-2.4 mg/dl), were also associated with $30.3 \%$ mortality rates. The adjustments for several clinical parameters such as albumin, BUN and age didn't change the results [28].

\section{Conclusion}

This study indicated that while serum zinc level was decreased in pregnants with COVID-19, serum copper and magnesium levels were increased compared to controls. It was the first time that the correlation between the zinc, copper and magnesium changes and acute phase reactants were shown in COVID-19 infection. These results showed zinc relation with COVID-19 disease which is recently debating. Furthermore, magnesium increase in pregnant women with COVID-19 should be concerned as magnesium is used as medication in obstetric field for especially in the treatment of cramps. Further 
research would be needed to evaluate the effects of trace elements on COVID-19 in pregnant and in general population which was shown with this study first time to date.

\section{Declarations}

Funding: None.

Conflict of interest: The authors declare that they have no conflict of interest.

Ethical approval: This study has been approved by the Ethics Committee of Ankara City Hospital and Turkish Ministry of Health (E1-20-1009).

Consent to participate: Not applicable

Consent for publication : Not applicable

Availability of data and material: Not applicable

Code availability: Not applicable

\section{References}

1. Elshafeey F, Magdi R, Hindi N, Elshebiny M, Farrag N, Mahdy S, Sabbour M, Gebril S, Nasser M and Kamel M (2020) A systematic scoping review of COVID-19 during pregnancy and childbirth. International Journal of Gynecology \& Obstetrics 150:47-52.

2. Zaigham M and Andersson $O$ (2020) Maternal and perinatal outcomes with COVID-19: A systematic review of 108 pregnancies. Acta obstetricia et gynecologica Scandinavica.

3. Della Gatta AN, Rizzo R, Pilu G and Simonazzi G (2020) COVID19 during pregnancy: a systematic review of reported cases. American Journal of Obstetrics and Gynecology.

4. Te Velthuis AJ, van den Worm SH, Sims AC, Baric RS, Snijder EJ and van Hemert MJ (2010) Zn2+ inhibits coronavirus and arterivirus RNA polymerase activity in vitro and zinc ionophores block the replication of these viruses in cell culture. PLoS pathogens 6 .

5. Terrin G, Berni Canani R, Di Chiara M, Pietravalle A, Aleandri V, Conte F and De Curtis M (2015) Zinc in early life: a key element in the fetus and preterm neonate. Nutrients 7:10427-10446.

6. Kardos J, Héja L, Simon Á, Jablonkai I, Kovács R and Jemnitz K (2018) Copper signalling: causes and consequences. Cell Communication and Signaling 16:1-22.

7. Ilbäck N-G, Frisk P, Tallkvist J, Gadhasson I-L, Blomberg J and Friman G (2008) Gastrointestinal uptake of trace elements are changed during the course of a common human viral (Coxsackievirus B3) infection in mice. Journal of Trace Elements in Medicine and Biology 22:120-130.

8. Cernat R, Mihaescu T, Vornicu M, Vione D, Olariu R and Arsene C (2011) Serum trace metal and ceruloplasmin variability in individuals treated for pulmonary tuberculosis. The International journal 
of tuberculosis and lung disease 15:1239-1245.

9. Besold AN, Culbertson EM and Culotta VC (2016) The Yin and Yang of copper during infection. JBIC Journal of Biological Inorganic Chemistry 21:137-144.

10. Kanellopoulou C, George AB, Masutani E, Cannons JL, Ravell JC, Yamamoto TN, Smelkinson MG, Jiang PD, Matsuda-Lennikov M and Reilley J (2019) Mg2+ regulation of kinase signaling and immune function. Journal of Experimental Medicine 216:1828-1842.

11. Ye M, Li Q, Xiao L and Zheng Z (2020) Serum Magnesium and Fractional Exhaled Nitric Oxide in Relation to the Severity in Asthma-Chronic Obstructive Pulmonary Disease Overlap. Biological Trace Element Research. doi: 10.1007/s12011-020-02314-5

12. Ahmadi S, Naderifar M, Samimi M, Mirhosseini N, Amirani E, Aghadavod E and Asemi Z (2018) The effects of magnesium supplementation on gene expression related to inflammatory markers, vascular endothelial growth factor, and pregnancy outcomes in patients with gestational diabetes. Magnesium research 31:131-142.

13. Alonso LG, Prieto MP, Colmenero EG, Guisán AC, Albo MS, Fernández-Feijoo CD, Durán LG and Lorenzo JF (2018) Prenatal therapy with magnesium sulfate and its correlation with neonatal serum magnesium concentration. American journal of perinatology 35:170-176.

14. Tanacan A, Erol SA, Turgay B, Anuk AT, Secen El, Yegin GF, Ozyer S, Kirca F, Dinc B and Unlu S (2020) The rate of SARS-CoV-2 positivity in asymptomatic pregnant women admitted to hospital for delivery: Experience of a pandemic center in Turkey. European Journal of Obstetrics \& Gynecology and Reproductive Biology.

15. ThePerkin-ElmerCorporation (1996) Analytical methods for atomic absorption spectroscopy. USA.

16. Prasad AS, Bao B, Beck FW and Sarkar FH (2011) Zinc-suppressed inflammatory cytokines by induction of A20-mediated inhibition of nuclear factor-KB. Nutrition 27:816-823.

17. Melichar B, Malír F and Tichý M (1993) Urinary zinc excretion in patients with different disorders: the acute phase response in the kidney. Sbornik vedeckych praci Lekarske fakulty Karlovy university $\mathrm{v}$ Hradci Kralove 36:325-335.

18. Unver $\mathrm{N}$ and McAllister F (2018) IL-6 family cytokines: Key inflammatory mediators as biomarkers and potential therapeutic targets. Cytokine \& growth factor reviews 41:10-17.

19. Germolec DR, Frawley RP and Evans E (2010) Markers of inflammation. Immunotoxicity Testing, Springer, pp. 53-73

20. Liuzzi JP, Lichten LA, Rivera S, Blanchard RK, Aydemir TB, Knutson MD, Ganz T and Cousins RJ (2005) Interleukin-6 regulates the zinc transporter Zip14 in liver and contributes to the hypozincemia of the acute-phase response. Proceedings of the National Academy of Sciences 102:6843-6848.

21. Aydemir TB, Chang S-M, Guthrie GJ, Maki AB, Ryu M-S, Karabiyik A and Cousins RJ (2012) Zinc transporter ZIP14 functions in hepatic zinc, iron and glucose homeostasis during the innate immune response (endotoxemia). PloS one 7:e48679.

22. Jothimani D, Kailasam E, Danielraj S, Nallathambi B, Ramachandran H, Sekar P, Manoharan S, Ramani V, Narasimhan G and Kaliamoorthy I (2020) COVID-19: Poor outcomes in patients with Zinc 
deficiency. International Journal of Infectious Diseases.

23. Huang $Y$, Zhang $Y$, Lin $Z$, Han $M$ and Cheng H (2018) Altered serum copper homeostasis suggests higher oxidative stress and lower antioxidant capability in patients with chronic hepatitis B. Medicine 97.

24. Moreno T, Artacho R, Navarro M, Perez A and Ruiz-Lopez M (1998) Serum copper concentration in HIV-infection patients and relationships with other biochemical indices. Science of the total environment 217:21-26.

25. Hafizi M, Mardani S, Borhani A, Ahmadi A, Nasri P and Nasri H (2014) Association of helicobacter pylori infection with serum magnesium in kidney transplant patients. Journal of renal injury prevention 3:101.

26. Lal CS, Kumar S, Ranjan A, Rabidas VN, Verma N, Pandey K, Verma RB, Das S, Singh D and Das P (2013) Comparative analysis of serum zinc, copper, magnesium, calcium and iron level in acute and chronic patients of visceral leishmaniasis. Journal of Trace Elements in Medicine and Biology 27:98102.

27. Garba I and Ubom G (2006) Potential role of serum magnesium measurement as a biomarker of acute falciparum malaria infection in adult patients. Biological trace element research 114:115-120.

28. Nasser R, Naffaa ME, Mashiach T, Azzam ZS and Braun E (2018) The association between serum magnesium levels and community-acquired pneumonia 30-day mortality. BMC Infectious Diseases 18:698.

\section{Tables}

Table 1. Clinical characterictics of SARS-CoV-2 (+) pregnants and controls 


\begin{tabular}{|c|c|c|c|c|c|}
\hline \multirow[t]{3}{*}{ Variables } & & \multicolumn{2}{|c|}{ SARS-CoV-2 (+) } & \multicolumn{2}{|l|}{ Control } \\
\hline & & Mean & SD & Mean & SD \\
\hline & & Median & Min-Max & Median & Min-Max \\
\hline \multirow{3}{*}{$\begin{array}{l}\text { Age } \\
\text { year }\end{array}$} & $1^{\text {st }}$ Trimester & $28^{*}$ & $17-38$ & $26^{*}$ & $19-34$ \\
\hline & $2^{\text {nd }}$ Trimester & 29 & $18-41$ & 27 & $17-41$ \\
\hline & $3^{\text {rd }}$ Trimester & 30 & $22-41$ & 26 & $19-41$ \\
\hline \multirow{3}{*}{$\begin{array}{l}\mathrm{BMI} \\
\mathrm{kg} / \mathrm{m}^{2}\end{array}$} & $1^{\text {st }}$ Trimester & 25,65 & 3,96 & 25,60 & 4,46 \\
\hline & $2^{\text {nd }}$ Trimester & 26,72 & 3,32 & 26,02 & 5,14 \\
\hline & $3^{\text {rd }}$ Trimester & 29,11 & 5,68 & 28,36 & 3,34 \\
\hline \multirow[t]{3}{*}{ Gestational Age } & $1^{\text {st }}$ Trimester & 8,5 & $5-14$ & 9 & $5-14$ \\
\hline & $2^{\text {nd }}$ Trimester & 25 & $17-28$ & 25 & $15-28$ \\
\hline & $3^{\text {rd }}$ Trimester & 35 & $29-39$ & 35 & $28-40$ \\
\hline \multirow[t]{3}{*}{ Gravidity } & $1^{\text {st }}$ Trimester & 2 & $1-7$ & 2 & $1-4$ \\
\hline & $2^{\text {nd }}$ Trimester & 2 & $1-7$ & 2 & $1-6$ \\
\hline & $3^{\text {rd }}$ Trimester & 2 & $1-7$ & 2 & $1-5$ \\
\hline \multirow[t]{3}{*}{ Parity } & $1^{\text {st }}$ Trimester & 1 & $0-5$ & 1 & $0-2$ \\
\hline & $2^{\text {nd }}$ Trimester & 1 & $0-6$ & 1 & $0-5$ \\
\hline & $3^{\text {rd }}$ Trimester & 1 & $0-4$ & 1 & $0-3$ \\
\hline \multirow{3}{*}{$\begin{array}{l}\text { WBC } \\
\text { per ml }\end{array}$} & $1^{\text {st }}$ Trimester & $5380 * \star$ & $3320-15620$ & 8300 ** & $3630-12860$ \\
\hline & $2^{\text {nd }}$ Trimester & $5970 * \star \star$ & $3490-10810$ & $9435^{\star \star \star}$ & $4040-15030$ \\
\hline & $3^{\text {rd }}$ Trimester & 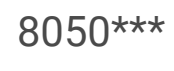 & $3930-14380$ & $9220 * \star *$ & $5400-14140$ \\
\hline \multirow{3}{*}{$\begin{array}{l}\text { Neutrophil } \\
\text { per ml }\end{array}$} & $1^{\text {st }}$ Trimester & $3735^{\star}$ & 1710-14030 & $5710 *$ & $2150-9460$ \\
\hline & $2^{\text {nd }}$ Trimester & 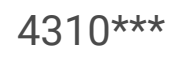 & $2350-8140$ & $6635^{\star \star \star}$ & $2750-11450$ \\
\hline & $3^{\text {rd }}$ Trimester & $5950 * \star \star$ & 2100-10160 & $6810 * \star \star *$ & $3830-10110$ \\
\hline \multirow{2}{*}{$\begin{array}{l}\text { Lymphocyte } \\
\text { per ml }\end{array}$} & $1^{\text {st }}$ Trimester & 1270 *** & $520-2600$ & 1900 *** & $460-2850$ \\
\hline & $2^{\text {nd }}$ Trimester & 1160 *** & $360-2220$ & $1815^{\star \star \star}$ & $930-3200$ \\
\hline
\end{tabular}




\begin{tabular}{|c|c|c|c|c|c|}
\hline & $3^{\text {rd }}$ Trimester & 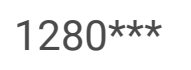 & $350-3330$ & $1700 * \star \star$ & $1070-3230$ \\
\hline \multirow{3}{*}{$\begin{array}{l}\text { CRP } \\
\mathrm{mg} / \mathrm{dl}\end{array}$} & $1^{\text {st }}$ Trimester & $13,2^{\star}$ & 14,48 & $7,36^{\star}$ & 7,9 \\
\hline & $2^{\text {nd }}$ Trimester & $29,49 *$ & 52,71 & $7,27 *$ & 4,92 \\
\hline & $3^{\text {rd }}$ Trimester & $22,93^{*}$ & 27,88 & $5,11^{\star}$ & 3,20 \\
\hline \multirow[t]{3}{*}{ ESR } & $1^{\text {st }}$ Trimester & $29,40 * \star \star$ & 5,71 & $15,78 * \star \star$ & 7,48 \\
\hline & $2^{\text {nd }}$ Trimester & 30,27 & 11,76 & 28,03 & 13,65 \\
\hline & $3^{\text {rd }}$ Trimester & 37,90 & 15,85 & 35,43 & 15,40 \\
\hline \multirow{3}{*}{$\begin{array}{l}\mathrm{lL}-6 \\
\mathrm{pg} / \mathrm{ml}\end{array}$} & $1^{\text {st }}$ Trimester & $8,53^{\star *}$ & 7,88 & 3,56 ** & 0,841 \\
\hline & $2^{\text {nd }}$ Trimester & 9,73 & 11,19 & 5,82 & 9,82 \\
\hline & $3^{\text {rd }}$ Trimester & 18,99 & 24,63 & 3,80 & 1,10 \\
\hline \multirow{3}{*}{$\begin{array}{l}\text { Procalcitonin } \\
\mathrm{ng} / \mathrm{ml}\end{array}$} & $1^{\text {st }}$ Trimester & $0,037 * \star$ & 0,01 & $0,026^{\star \star}$ & 0,005 \\
\hline & $2^{\text {nd }}$ Trimester & 0,35 & 1,73 & 0,026 & 0,005 \\
\hline & $3^{\text {rd }}$ Trimester & 0,05 & 0,04 & 0,03 & 0,01 \\
\hline \multirow{3}{*}{$\begin{array}{l}\text { Ferritin } \\
\mathrm{ng} / \mathrm{ml}\end{array}$} & $1^{\text {st }}$ Trimester & 39,44 & 50,35 & 22,78 & 20,21 \\
\hline & $2^{\text {nd }}$ Trimester & 61,03 & 156,11 & 14,10 & 9,17 \\
\hline & $3^{\text {rd }}$ Trimester & 31,39 & 38,95 & 13,45 & 16,20 \\
\hline \multirow{3}{*}{$\begin{array}{l}\text { Haemoglobin } \\
\text { g/dl }\end{array}$} & $1^{\text {st }}$ Trimester & 12,46 & 1,08 & 12,86 & 1,04 \\
\hline & $2^{\text {nd }}$ Trimester & $11,20 *$ & 1,14 & $12,05^{\star}$ & 0,99 \\
\hline & $3^{\text {rd }}$ Trimester & 10,96 ** & 1,16 & $11,46^{\star \star}$ & 0,98 \\
\hline \multirow{3}{*}{$\begin{array}{l}\text { Hematocrit } \\
\%\end{array}$} & $1^{\text {st }}$ Trimester & $37,45^{\star}$ & 2,80 & $38,97 *$ & 3,15 \\
\hline & $2^{\text {nd }}$ Trimester & $34,25^{\star}$ & 3,43 & $37,12^{*}$ & 2,93 \\
\hline & $3^{\text {rd }}$ Trimester & $33,58^{\star \star}$ & 3,22 & $35,62^{\star \star}$ & 2,66 \\
\hline \multirow{3}{*}{$\begin{array}{l}\text { BUN } \\
\mathrm{mg} / \mathrm{dl}\end{array}$} & $1^{\text {st }}$ Trimester & 18,55 & 4,80 & 19,63 & 5,61 \\
\hline & $2^{\text {nd }}$ Trimester & $14,36 *$ & 4,08 & $17,59 *$ & 3,90 \\
\hline & $3^{\text {rd }}$ Trimester & $16,39 * *$ & 7,25 & $16,85^{\star \star}$ & 4,35 \\
\hline
\end{tabular}




\begin{tabular}{|c|c|c|c|c|c|}
\hline \multirow{3}{*}{$\begin{array}{l}\text { Creatinine } \\
\mathrm{mg} / \mathrm{dl}\end{array}$} & $1^{\text {st }}$ Trimester & 0,53 & 0,08 & 0,55 & 0,07 \\
\hline & $2^{\text {nd }}$ Trimester & 0,45 & 0,09 & 0,47 & 0,08 \\
\hline & $3^{\text {rd }}$ Trimester & 0,47 & 0,09 & 0,47 & 0,08 \\
\hline \multirow{3}{*}{$\begin{array}{l}\text { ALT } \\
\text { IU }\end{array}$} & $1^{\text {st }}$ Trimester & 29,26 & 26,15 & 20,75 & 17,46 \\
\hline & $2^{\text {nd }}$ Trimester & $31,90 *$ & 33,70 & $18,90 *$ & 8,39 \\
\hline & $3^{\text {rd }}$ Trimester & $20,63^{*}$ & 13,59 & $13,55^{\star}$ & 13 \\
\hline \multirow{3}{*}{$\begin{array}{l}\text { AST } \\
\text { IU }\end{array}$} & $1^{\text {st }}$ Trimester & $22,41 *$ & 15,25 & $14,57^{\star}$ & 7,64 \\
\hline & $2^{\text {nd }}$ Trimester & $41,87^{*}$ & 63,91 & $15,59 *$ & 4,47 \\
\hline & $3^{\text {rd }}$ Trimester & $23,03^{*}$ & 13,12 & $15,35^{\star}$ & 3,96 \\
\hline
\end{tabular}

ALT: Alanine Aminotransferase, AST: Aspartate Aminotransferase, BUN: Blood urea nitrogen, CRP: CReactive Protein, ESR: Erythrocyte Sedimentation Rate , IL: Interleukine, IU: International Unit, SD: Standart Deviation, WBC: White Blood Cell. ${ }^{*} p<0.05,{ }^{* *} p<0.01,{ }^{* \star *} p<0.001$

\section{Figures}




\section{$1^{\text {st }}$ Trimester}
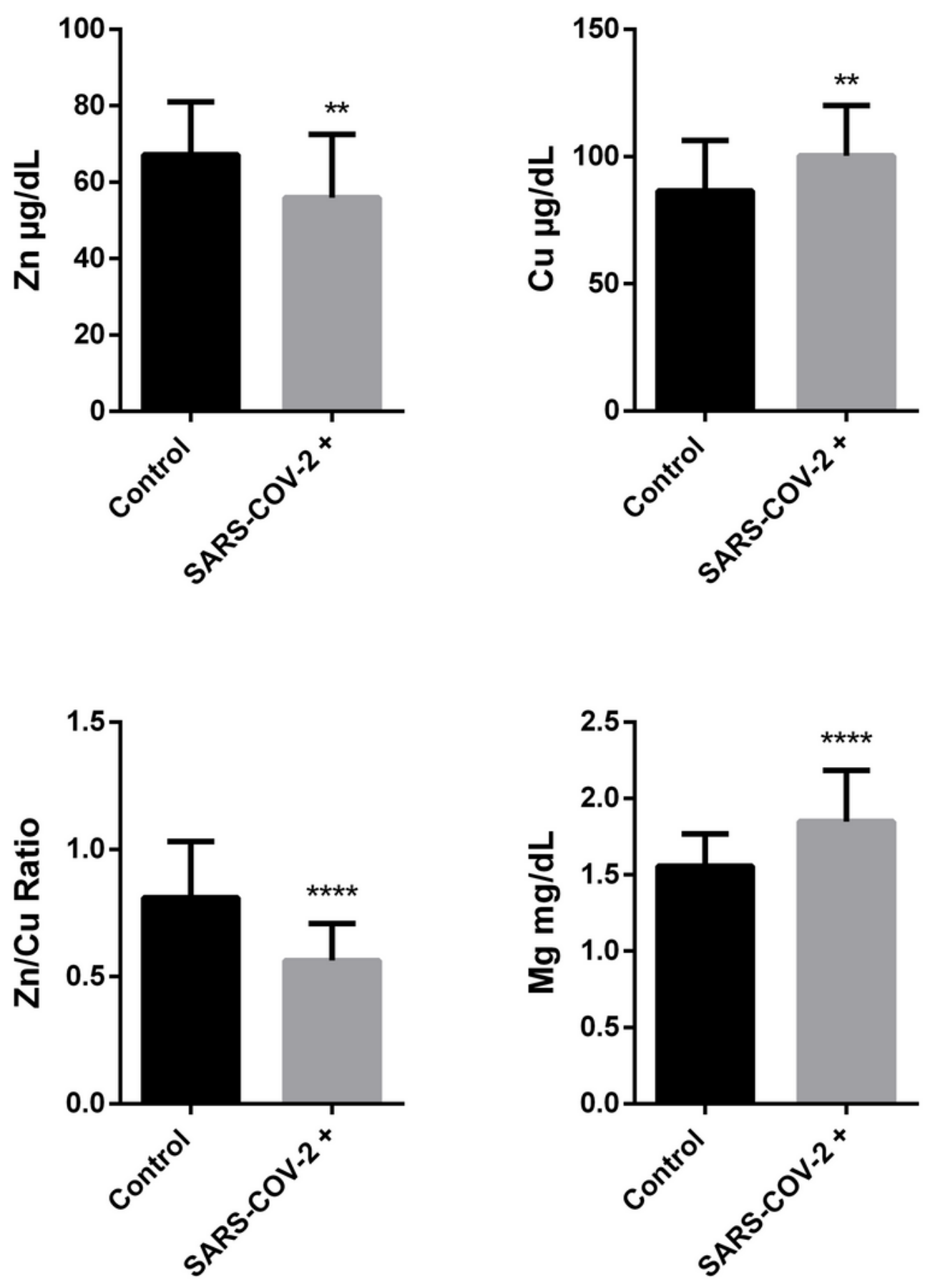

Figure 1

Trace element results in first trimester of SARS-Cov-2 (+) and control group.(Mean $\pm S D,{ }^{*}<<0.05$, $\star \star p<0.01, * \star \star p<0.001, * \star \star \star p<0.0001)$. 


\section{$2^{\text {nd }}$ Trimester}
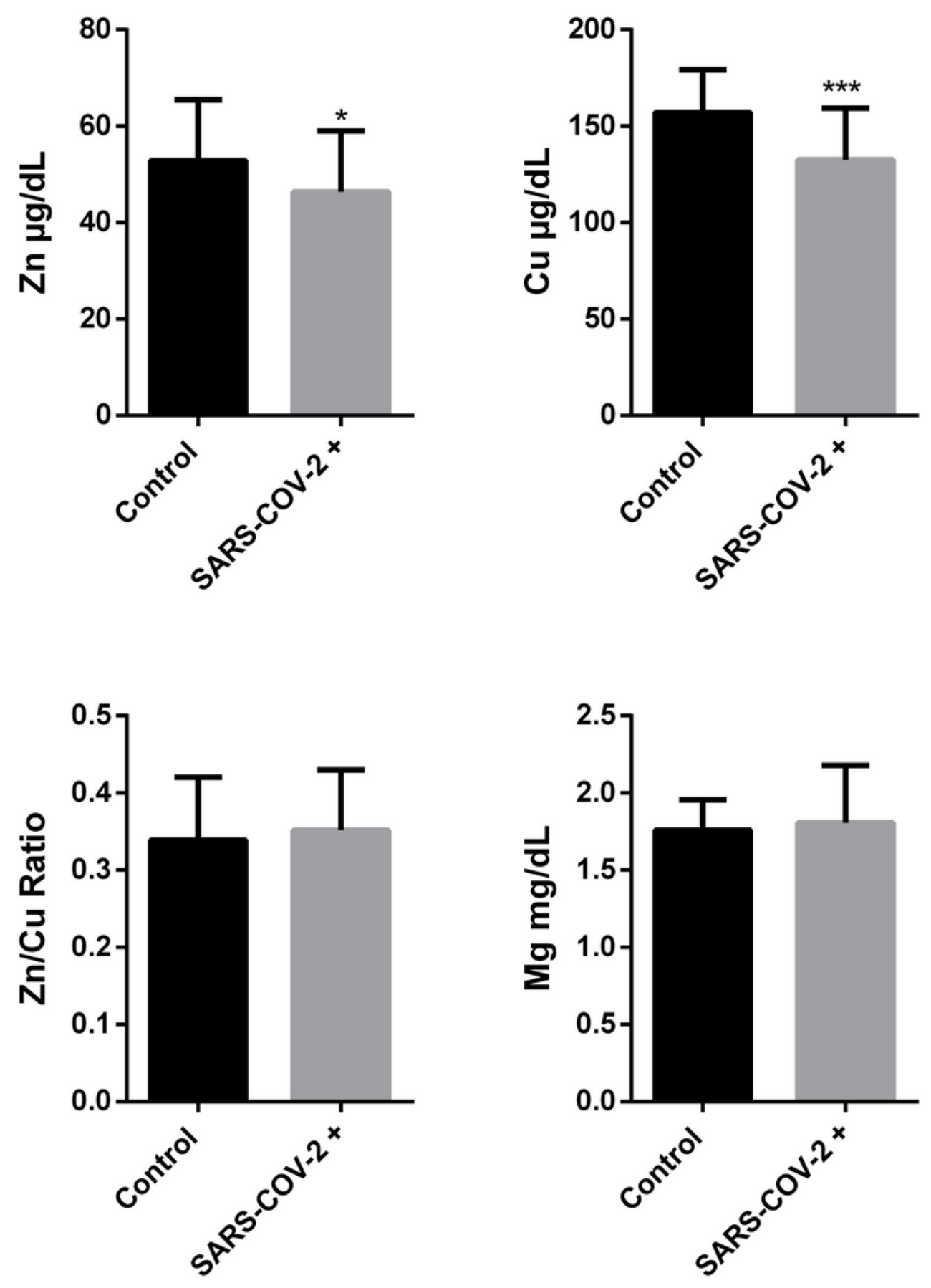

Figure 2

Trace element results in second trimester of SARS-Cov- $2(+)$ and control group.(Mean $\pm S D,{ }^{*} p<0.05$, $\star \star p<0.01, * \star \star p<0.001, * \star \star \star p<0.0001)$. 


\section{$3^{\text {rd }}$ Trimester}
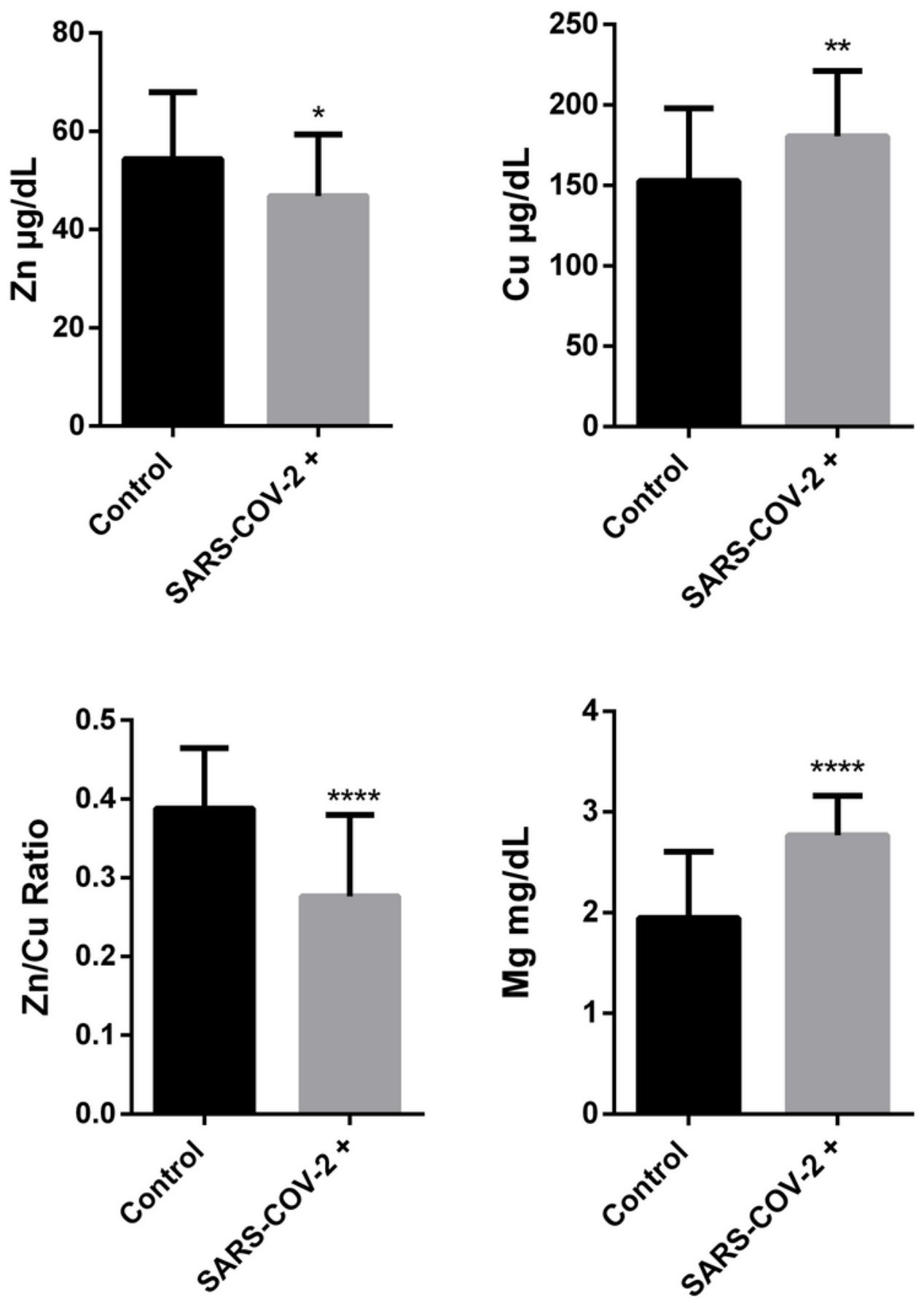

Figure 3

Trace element results in third trimester of SARS-Cov-2 $(+)$ and control group.(Mean \pm SD, ${ }^{*} p<0.05$, $\star \star p<0.01, * \star \star p<0.001, * \star \star \star p<0.0001)$. 


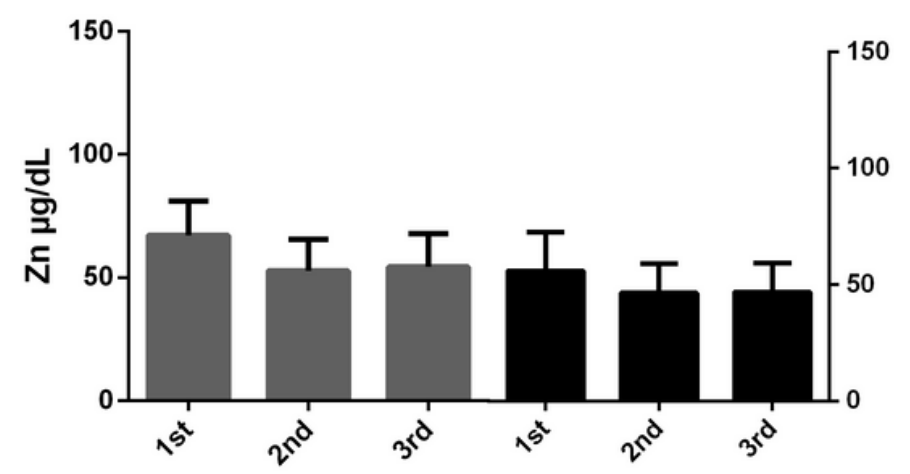

Control Group

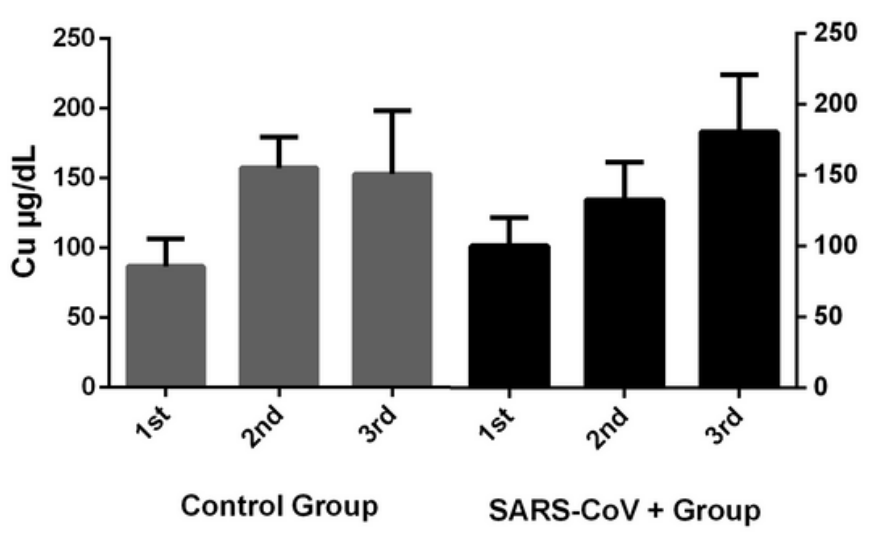

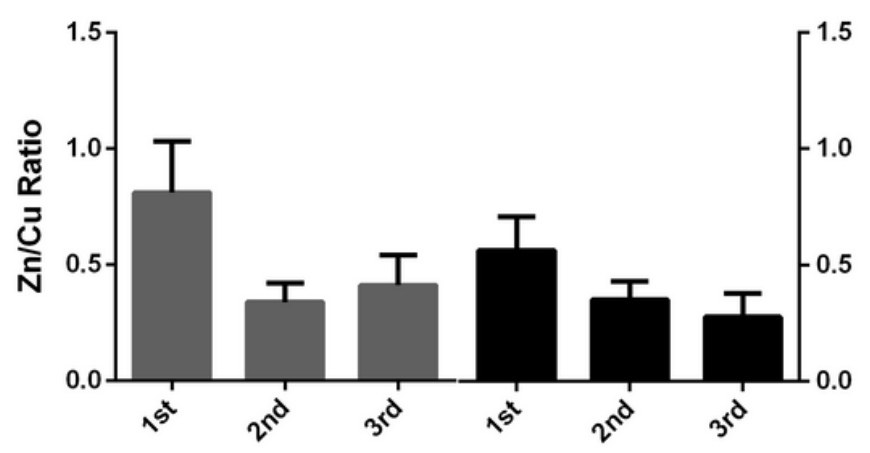

Control Group

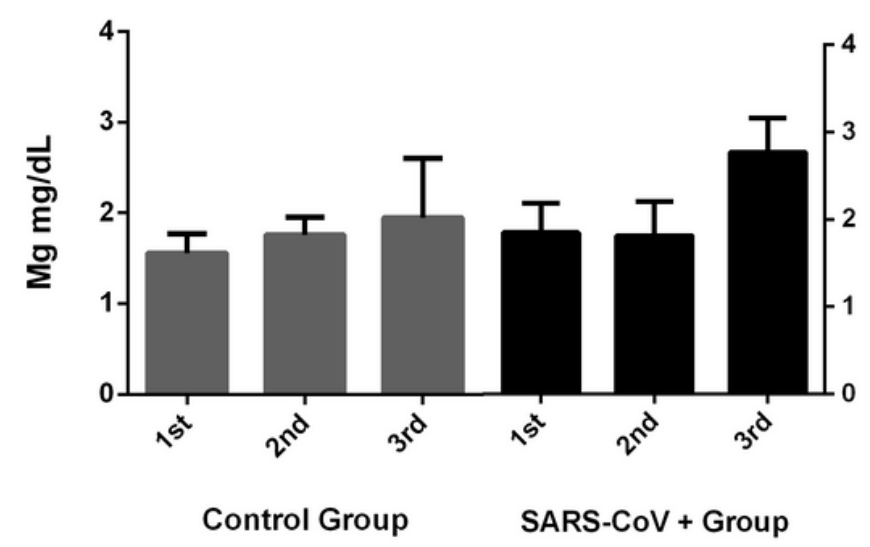

Figure 4

Changes in trace element concentrations of SARS-CoV-2 (+) and control groups during pregnancy according to trimesters. 